\title{
The Antioxidant Effect of PLGA Nanoparticles Encapsulated with Lutein in Rats Treated with Hypercaloric Diet
}

\author{
CATALINA RADULESCUㄹ, DANIELA MIRICESCU*, BOGDAN CALENIC ${ }^{1 *}$, RADU RADULESCU $^{1}$, IULIA STANESCUㄹ, ANCA CALENIC ${ }^{1}$, \\ ALEXANDRA TOTAN ${ }^{1}$, BOGDANA VIRGOLICI ${ }^{2}$, DANIELA BALAN ${ }^{3}$, MARIA GREABU ${ }^{1}$ \\ IUniversity of Medicine and Pharmacy Carol Davila, Faculty of Dental Medicine, Department of Biochemistry, 8 Eroii Sanitari \\ Blvd, 050474, Bucharest, Romania \\ ZUniversity of Medicine and Pharmacy Carol Davila, Faculty of General Medicine, Department of Biochemistry, 8 Eroii Sanitari \\ Blvd, 050474, Bucharest, Romania \\ ${ }^{3}$ University of Medicine and Pharmacy Carol Davila, Faculty of Dental Medicine, Department of Physiology, 8 Eroii Sanitari Blvd, \\ 050474, Bucharest, Romania
}

\begin{abstract}
Poly lactic-co-glycolic acid (PLGA) is a biodegradable polymer that has been the focus of intense research due to its potential applications in medical research. Its uses in nanotechnology are underlined by its capability of targeting various cells and delivering active compounds to different human tissues. To date, PLGA nanoparticles are employed in areas such as vaccination therapy, diagnostic imaging procedure and various applications in various anticancer therapies. The aim of the present study is to measure and evaluate different correlations between oxidative stress parameters in spleen and liver following administration of nanoparticles encapsulated with lutein in an animal model. Our results show that acute oral administration of PLGA NPS induces a change in the oxidative stress status in both liver and spleen of rats, but does not induce oxidative stress damage to cell structures such as lipids or proteins.
\end{abstract}

Keywords: polymeric nanoparticles, oxidative stress, liver, spleen, animal study

The field of nanotechnology has seen an increasing interest in the last years. Nanomaterials can be natural or synthetic and their particle size can range between 0.1 to $100 \mathrm{~nm}[1]$. Based on their chemical composition, nanoparticles can be classified as carbon based, metal based, polymers or composite[2]. Another classification is based on shape and structural organization, ranging from nanoparticles, nanotubes, nanofilms to nanofibers [1]. Synthetic materials are preferable to natural ones due to their higher purity and reproducibility[2]. Usually NP dimensions range between $0,1 \mu \mathrm{m}$ and $100 \mathrm{~nm}$ [3]. NP used as drug carriers tend to be over $100 \mathrm{~nm}$ due to the high functional surface, big enough to adsorb and carry drugs [4].

Poly lactic-co-glycolic acid (PLGA) is one of the most used synthetic biodegradable polymers in the modern medical research due to its appealing properties such as biodegradability, biocompatibility, flexibility and reduced side-effects [5]. It is a copolymer of poly lactic acid (PLA) and poly glycolic acid (PGA). The asymmetric carbon in poly lactic acid is responsible for the two enantiomer forms poly D-lactic acid (PDLA) and poly L-lactic acid (PLLA), PLGA nanoparticles contain both these forms in equal proportions [6]. PLGA is approved by the United States Food and Drug Administration (FDA) due to its biodegradability through hydrolysis into monomeric forms (lactic acid and glycolic acid), both natural occurring compounds in the Krebs cycle [7].

$$
\begin{gathered}
\mathrm{CH}_{3}-\mathrm{CH}(\mathrm{OH})-\mathrm{COOH}(\text { lactic acid })+ \\
\mathrm{CH}_{2}(\mathrm{OH})-\mathrm{COOH}(\text { glycolic acid }) \\
\stackrel{\text { polycondensation }}{\longrightarrow} \\
\stackrel{\mathrm{HO}\left(-\mathrm{CH}\left(\mathrm{CH}_{3}\right)-\mathrm{COO}-\mathrm{CH}_{2}-\mathrm{COO}-\right)_{n}}{\stackrel{\text { degradation (hydrolysis:human body) }}{\longrightarrow}}
\end{gathered}
$$

*email: daniela.miricescu@umfcd.ro; bogdan.calenic@umfcd.ro

$$
\begin{gathered}
\rightarrow \quad \mathrm{CH}_{3}-\mathrm{CH}(\mathrm{OH})-\mathrm{COOH}+ \\
\mathrm{CH}_{2}(\mathrm{OH})-\mathrm{COOH} \\
\stackrel{\text { Krebs cycle }}{\longrightarrow} \mathrm{CO}_{2}+\mathrm{H}_{2} \mathrm{O}
\end{gathered}
$$

Fig. 1.Polycondensation of lactic and glycolic acid into PLGA and degradation through hydrolysis

A distinct advantage of PLGA NP's is that it can be designed to obtain certain properties. A broad spectrum of characteristics can be obtained by shaping two key properties such as key component composition (byaltering lactic acid and glycolic acid ratio) and stereoisomeric composition (either $L$ or $D$ ). Due to its ratio of glycolic acid units, PLGA can be soluble in most common organic solvents such as halogenated hydrocarbons (chloroform and dichloromethane), ethyl acetate, acetone, dioxan, and tetrahydrofuran. This solubility occurs when glycolic acid ratio is less than $50 \%$. If the concentration of glycolic acid is higher than $50 \%$ then PLGA NP's are insoluble in most organic solvents[8].

Cristallinity of NP'S affects the rate of degradation and mechanical properties of PLGA and is dependent by the chemical ratio of lactide=glycolide[8].

Polymeric nanoparticles consists of a matrix of polymers in which the polymers form a protection surrounding the core thus encapsulating the bioactive substance, therefore protecting itfrom degradation. In vivo, behavior of nanoparticles is affected by particle properties, such as size and surface charge. Concentration of surfactant affects it's properties such as size, zeta potential or hydrophobicity[9]. In this study, lutein was encapsulated in PLGA nanoparticles using PVA (polyvinyl alcohol) to improve its efficiency as an antioxidant.

PLGA are thermoplastic materials that have an acceptable heat resistance in absence of moisture, therefore can be processed to produce surgical fixation devices and drug delivery systems. PLGA degrades to lactic and glycolic acid after heating above $200^{\circ} \mathrm{C}$, under vacuum 
or nitrogen, in a prolonged environment. At lower temperatures, thermal degradation is accelerated by impurities, humidity and residual monomers [8] .

Degradation of PLGA NP's is affected by various chemical factors such as chemical composition (lactic acid and glycolic acid ratio), monomer distribution pattern and polymer purity or $\mathrm{pH}$ and medium temperature. Physical factors that affects NP's degradation range from NP's properties such as size, shape and porosity to the temperature of melting or sterilization[8].

One use of PLGA nanoparticles can be as a drug delivery system due to their numerous advantages such as: increased cellular permeability and retention, specific targeted drug delivery, slow release rate, reduced drug quantity and drug protection against degradation[2]. Also these nanoparticles can protect different molecules such as nucleic acids, peptides and protein antigens, raising the delivery capability of these molecules [10]. Their efficiency as a drug carrier depends on the drug encapsulation capacity or drug surface loading rate [11].

Oxidative stress (OS) is caused by an imbalance between increased levels of reactive oxygen species (ROS) and decreased cellular antioxidants [12]. ROS production is a consequence of aerobic metabolism (during mitochondrial oxidative metabolism) $[13,14]$ or can be generated as a response to xenobiotics, cytokines or bacterial invasion [12]. Phagocytosis of nanoparticles can generate OS by activating NADPH system and reduction of one electron from $\mathrm{O}_{2}$ to form superoxide anion $\mathrm{O}_{2} \cdot[2]$. The result of OS is damage to biomolecules such as nucleic acids, proteins and lipids [15].

OS can be determined using markers of OS damage such as malondialdehyde (MDA) or markers of antioxidant defense such as glutathione (GSH).

MDA is one of the most used biomarkers of OS [16]. It is a product of lipid peroxidation of arachidonic acid and other polyunsaturated fatty acids caused by OS, hydroxyl radical $\mathrm{HO}^{\circ}$ and the hydroperoxyl radical $\mathrm{HO}_{2}{ }_{2}$ being the most important ones [17].

GSH is a tripeptide composed of glutamic acid, cysteine and glycine and is one of the most important intracellular antioxidants [18]. It exists in the reduced form (GSH) or in the oxidized form (GSSG) acting as a scavenger for ROS (particularly $\mathrm{HO}^{-}$and $\mathrm{HO}_{2}{ }_{2}$ ) [19] or as an enzymatic cofactor for the selenium-dependent glutathione peroxidase (GPX) [20].

Lutein is a carotenoid, a member of the xanthophyll family, which is only produced by plants thus being accumulated in the animal system only by diet (dark green leafy vegetables) [21]. ROS scavenger role of lutein is based on the chemical structure containing two hydroxyl groups that react with free radicals [22]. Lutein is present in the macular region of the eye and has different roles such as a free radical scavenger protecting against macular damage and acting as a pigment for absorbing high energy blue light and protecting photoreceptors from photo toxicity[23, 24]. Apart from the antioxidant properties recent studies have shown that dietary lutein can down-regulate the inflammatory responses in animal liver, butthe mechanism has not been fully investigated [25]. Other studies on animal models fed with a with high cholesterol diet proved that a diet containing lutein can decrease oxidative stress by reducing lipid peroxidation and can prevent degenerative conditions due to lower pro inflammatory cytokine production, especially in the liver, where it accumulates in high doses [25].

One important problem in oral drug administration is that the delivery path undergoes acidic and enzymatic degradation. Nanoparticles can be an efficient alternative to deliver drugs that are poorly absorbed due to their properties to carry both hydrophilic and hydrophobic drug molecules [26].

Due to their minimal size, NP can pass through the tight junctions of the gutepithelial cells and reach the circulatory system. Several studies on animal models found that NP concentrate in several organs such as the spleen and liver of mice and rats (the liver having the highest concentration of NP) [26-28].

Another study found lower MDA levels in hypercholesterolemic rats after intake of a antioxidant diet, levels similar to the normocholesterolemic rats after an antioxidant diet consisting in rich phenolic fruits [29].

Our previous studies showed that PLGA NP uptake depends on the cell type; thus oral keratinocytes, fibroblasts, pulp cells, oral cancer cells internalized organic NP at different concentrations and time points[2, 5, 30,31]. At the same time we expanded the in vitro studies to in vivo animal models and analyzed the OS effects of PLGA NP on rats. Past study has shown that PLGA activates the OS defense system, butdoesn'tincrease significantly the levels of MDA and GSH in spleen and liver homogenate from an animal model [2].

The present study is expanding on our previous findings and is focusing on OS changes in an animal model exposed to polymeric nanoparticles loaded with lutein, the target being the determination of key OS-related molecules, such as GSH and lipid peroxidation in rats spleen and liver.

\section{Experimental part}

PLGA nanoparticles preparation

The method was previously described in an article [2].

\section{Animal model}

The animal model consisted of 3 groups of 5 male Wistar rats each (age 3 months) who were fed with a hypercaloric diet, consisting of carbohydrates and lipids (butter and sugar), for 21 days. The control group (0) did not take any supplement and received only the hypercaloric diet. The nanoparticles group $(N)$ received in the morning a single dose of nanoparticles with PLGA 50 $\mathrm{mg} / \mathrm{kg}$ body associated to the diet, while the lutein $(\mathrm{L})$ group took a single dose of PLGA loaded with lutein 50 $\mathrm{mg} / \mathrm{kg}$ body in parallel with hypercaloric diet, by gavaje.

The rats were obtained from the Animal Facility of Carol Davila University of Medicine and Pharmacy, Bucharest, Romania and the experimental procedures were carried out under Convention 86/609/E.E.C. from November 24, 1986, for the Protection of Vertebrate Animals Used for Experimental and other Scientific Purposes. After three weeks, the rats were sacrificed and tissue samples (spleen and liver) had been collected. The homogenate had been obtained using $\mathrm{KCl} 25 \%$. OS biomarkers such as MDA and GSH were measured on liver and spleen tissue homogenates.

\section{Oxidative stress markers}

GSH was analyzed using the colorimetric method in which a yellow color was generated when $5,5^{\prime}$-dithiobis(2-nitrobenzoic acid) (DTNB) reacted with the sulfhydryl groups of GSH. Absorbance reading was done at $412 \mathrm{~nm}$ and the results were quantified using the molar extinction coefficient (an adapted method after Beutler) [32] .

The other OS marker analyzed was MDA which is formed after lipid hydroperoxide breakdown. The production of this substance is used as a biomarker to measure the level of lipid peroxidation. The method for 
MDA analysis is based on the reaction between MDA and thiobarbituric acid (TBA). The compounds are heated and generate a complex which can be spectrophometrically determined [33].

The method used $250 \mu \mathrm{L}$ of homogenate (liver/ spleen) that was mixed thoroughly with $2.25 \mathrm{~mL}$ working reactive - $10 \mathrm{~mL}$ tricholoroacetic acid (20\%) and $30 \mathrm{~mL}$ TBA (dissolved in $\mathrm{HClO}_{4}$ ). The controls contained $250 \mu \mathrm{L}$ of $\mathrm{KCl}$ mixed thoroughly with $2.25 \mathrm{~mL}$ working reactive. Both the samples and the controls were heated in boiling water $(20$ minutes) then cooled to room temperature. Centrifugation followed at $5000 \mathrm{rpm}$ for 10 minutes. The absorbance of the samples and the controls was measured at $532 \mathrm{~nm}$.

\section{Statistical Analysis}

Statistical analysis was performed using Student'st-test to compare and correlate clinical parameters with biochemical biomarkers. Statistical significance was set at a $p$-value of $<0.05$.

\section{Results and discussions}

The rats were sacrificed 21 days after acute administration of nanoparticles. GSH and MDA levels were analyzed in both liver and spleen from PLGA, PLGA and lutein and control groups and we obtained the following results: GSH $-0.79 \pm 0.01 \mu \mathrm{mol} / \mathrm{g}$ protein for the 0 group; $0.8 \pm 0.01 \mu \mathrm{mol} / \mathrm{g}$ protein for $\mathrm{N}$ group; $1 \pm 0.01 \mu \mathrm{mol} / \mathrm{g}$ protein for $L$ group for spleen.

GSH results for liver: $0.49 \pm 0.07 \mu \mathrm{mol} / \mathrm{g}$ protein for Ogroup; $0.54 \pm 0.07 \mu \mathrm{mol} / \mathrm{g}$ protein for $\mathrm{N}$ group and $0.63 \pm 0.07 \mu \mathrm{mol} / \mathrm{g}$ protein for $L$ group. GSH levels both in spleen and liver were elevated between the 3 groups, with highest values for the $L$ group as shown in figure 2 and 3 .

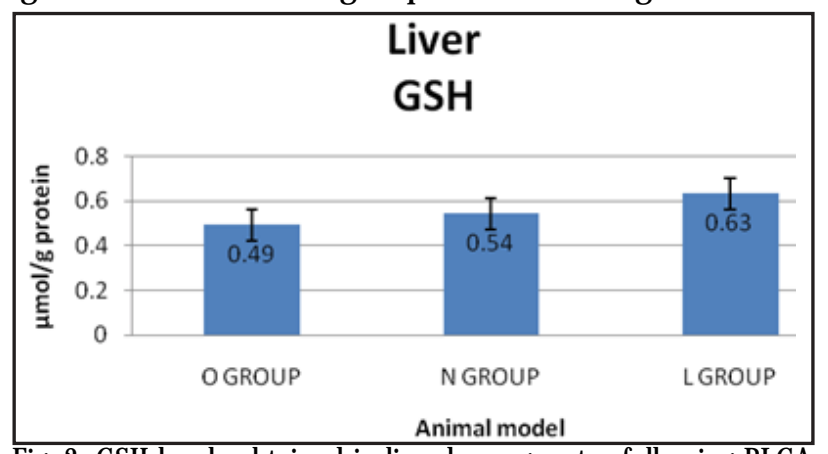

Fig. 2. GSH levels obtained in liver homogenates following PLGA exposure. Data is presented as mean values \pm standard deviation

\section{Spleen}

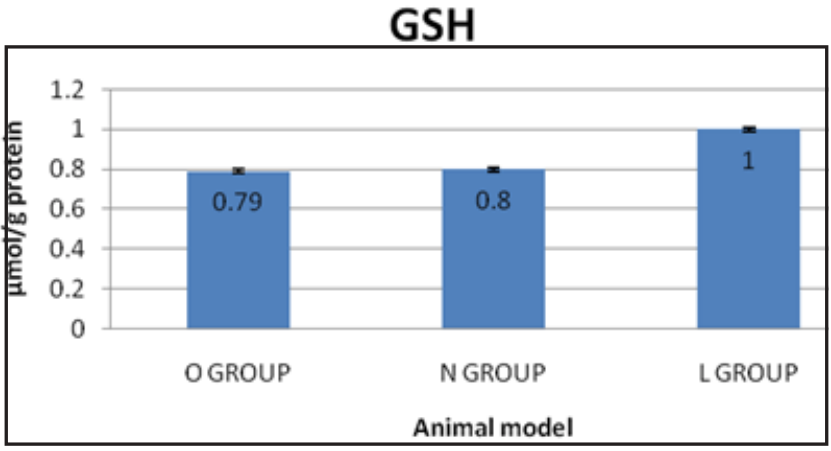

Fig.3. GSH levels obtained in spleen homogenates following PLGA exposure. Data is presented as mean values \pm standard deviation

MDA levels were $0.018 \pm 0.005 \mathrm{nmol} / \mathrm{g}$ protein for 0 group; $0.016 \pm 0.005 \mathrm{nmol} / \mathrm{g}$ protein for $\mathrm{N}$ group; $0.01 \pm 0.005$ $\mathrm{nmol} / \mathrm{g}$ protein for $\mathrm{L}$ group for spleen and $0.031 \pm 0.004$ $\mathrm{nmol} / \mathrm{g}$ protein for 0 group; $0.02 \pm 0.004 \mathrm{nmol} / \mathrm{g}$ protein for $\mathrm{N}$ group; $0.017 \pm 0.004 \mathrm{nmol} / \mathrm{g}$ protein for $\mathrm{L}$ group for liver.

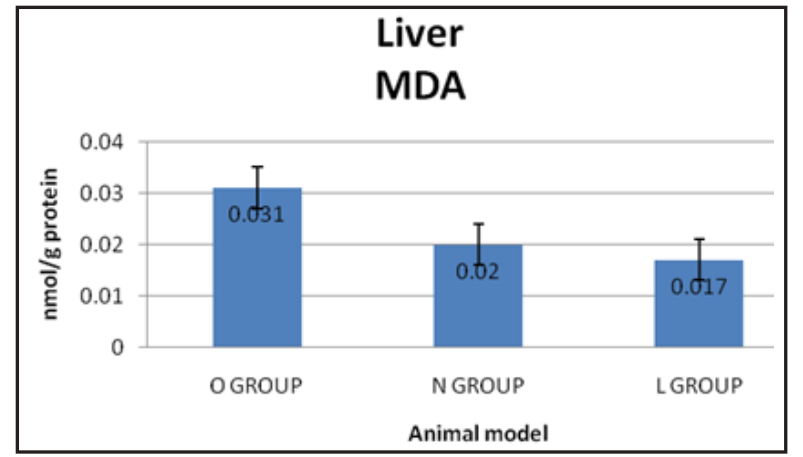

Fig. 4. MDA levels obtained in liver homogenates following PLGA exposure. Data is presented as mean values \pm standard deviation

Statistical analysis shows that MDA levels in liver and spleen were decreased for the $L$ group versus 0 group, with statistically significant differences. Between $\mathrm{N}$ and $\mathrm{O}$ groups we didn't observe statistically significant differences as shown in figure 4 and 5.

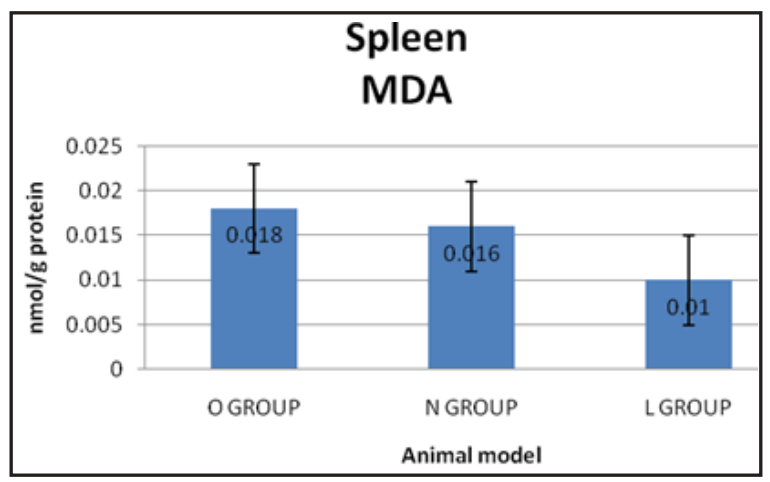

Fig. 5. MDA levels obtained in spleen homogenates following acute PLGA exposure. Data is presented as mean values \pm standard

This study was based on the premise that a hypercaloric diet induce oxidative stress in rats causing hepatic steatosis and cellular hypertrophy as shown in previous studies [34, 35]. Our working hypothesis was that PLGA NP's loaded with lutein increase the antioxidant defenses due to lutein antioxidant potential[25].

Our reason for studying PLGA NP's are based on their attributes: surface/ weight ratio,the ability to carry and release different macromolecules in a controlled manner[36]. The range of compounds that can be carried by NP vary from drugs, peptides, antioxidantsetc[1].

Second reason was determined by the fact that PLGA NP are degraded by hydrolysis of the esteric bond, the resulting monomers (lactic and glycolic acids) further enter the Krebs cycle. These two monomers are naturally occurring compounds which determines the good biocompatibility and low toxicity of these NP's[1].

Recent studies have shown that hypercaloric diet in animal model induces a moderate inflammatory state and dyslipidemia depleting antioxidant defenses and increasing markers of OS damage confirmed in our study by low levels of GSH and high levels of MDA in group $0[37,38]$.

Concerning GSH, we have noticed no significant difference between $\mathrm{O}$ and $\mathrm{N}$ groups, in both spleen and liver.

Regarding MDA, our results illustrated a significant difference between group $\mathrm{O}$ and $\mathrm{N}$. This result could be explained by the high concentrations of PLGA, coupled with the long period of administration, causing some toxic effects, probably based on inflammatory reactions. In normal conditions PLGA administration should not induce toxic effects[39]. 
In our study we have noticed that GSH level for group L (both in liver and spleen) was significantly increased compared to $\mathrm{N}$ and $\mathrm{O}$ groups. At the same, in L group, MDA levels significantly decreased compared to 0 and $N$ group. There are recentstudies illustrating thathigh lipid diet cause 0 status imbalance, mainly due to inflammatory reactions[37, 38].

Our results confirm the hypothesis that dietary lutein can have efficient $\mathrm{AO}$ effect. Lutein concentrates in liver and spleen and act as an $\mathrm{AO}$, probably lowering proinflammatory cytokines production[25].

After our knowledge, there are no previous studies about antioxidant effect of lutein encapsulated in PLGA in high lipid diet rats. Our results support the hypothesis that encapsulated lutein can act as an efficient antioxidant.

The findings of the present study need to be expanded in further studies by including shorter exposure times, with various PLGA concentrations, proposing and analyzing more oxidative stress markers and assessing NP effects in other tissues and organs.

\section{Conclusions}

The study shows that NP encapsulated with lutein activate GSH antioxidant defense system in spleen and liver, with increased results for the group $L$. Regarding MDA our results indicate that PLGA NP decrease MDA levels in liver and spleen homogenates, with better results for the lutein group. Therefore, we can conclude that administration of PLGA NP's provided protection against oxidative stress damage and usage of dietary lutein can act as an antioxidant for spleen and liver in an animal model. Furthermore, more research on oral delivery of PLGA NPs using chronic doses is needed in order to fully understand particle behavior in vivo.

\section{References}

1.LU, J.M., WANG, X., MARIN-MULLER, C.,WANG, H., LIN, P.H., YAO, Q., AND CHEN, C. Expert Rev Mol Diagn, 9, no.4, 2009, p. 325-41. 2.MIRICESCU, D., STANESCU, I., PERLEA, P., CALENIC, B., RADULESCU, R., TOTAN, A., VIRGOLICI, B., SABLIOV, C., GREABU, M. Mat. Plast., 54, no.2, 2017, p. 249.

3.STEVENSON, R., HUEBER, A.J., HUTTON, A., MCINNES, I.B., AND GRAHAM, D. ScientificWorldJ ournal, 11, 2011, p. 1300-12.

4.DE J ONG, W.H. AND BORM, P.J .A. Int J Nanomedicine, 3, no.2, 2008, p. 133-49.

5.VIRLAN, M.J.R., MIRICESCU, D., TOTAN, A., GREABU, M., TANASE, C., SABLIOV, C.M., CARUNTU, C., CALENIC, B. J ournal of Chemistry, 2015, 2015, p. 1-12.

6.MAKADIA, H.K., SIEGEL, S.J. Polymers (Basel), 3, no.3, 2011, p. 1377-1397.

7.GENTILE, P., CHIONO, V., CARMAGNOLA, I., AND HATTON, P.V. Int J Mol Sci, 15, no.3, 2014, p. 3640-59.

8.AVGOUSTAKIS, K. Encyclopedia of biomaterials and biomedical engineering. New York: Informa Healthcare USA, Inc, 2008, p. 225969.

9.MOHAMED, F. AND VAN DER WALLE, C.F. J Pharm Sci, 97,no.1, 2008, p. 71-87.

10.NICOLETE, R., DOS SANTOS, D.F., AND FACCIOLI, L.H. Int Immunopharmacol, 11, no.10, 2011, p. 1557-63.

11.KUMARI, A., YADAV, S.K., AND YADAV, S.C. Colloids Surf B Biointerfaces, 75, no.1, 2010, p. 1-18.
12.RAY, P.D., HUANG, B.W., AND TSUJI, Y. Cell Signal, 24, no.5, 2012, p. $981-90$

13.GUPTA, R.K., PATEL, A.K., SHAH, N., CHAUDHARY, A.K., JHA, U.K., YADAV, U.C., GUPTA, P.K., AND PAKUWAL, U. Asian Pac J Cancer Prev, 15, no.11, 2014, p. 4405-9.

14.FILOMENI, G., DE ZIO, D., AND CECCONI, F. Cell Death Differ, 22, no.3, 2015, p. 377-88.

15.BIRBEN, E., SAHINER, U.M., SACKESEN, C., ERZURUM, S., AND KALAYCI, 0. World Allergy Organ J, 5, no.1, 2012, p. 9-19.

16.KHOUBNASABJAFARI, M. Biolmpacts5, no.3, 2015, p. 123-7.

17.AYALA, A., MUNOZ, M.F., AND ARGÜELLES, S. Oxid Med Cell Longev, 2014, 2014.

18.ZITKA, O., SKALICKOVA, S., GUMULEC, J., MASARIK, M., ADAM, V., HUBALEK, J., TRNKOVA, L., AND KRUSEOVA, J. Oncol Lett4, no.6, 2012, p. 1247-53.

19.LUSHCHAK, V.I. J Amino Acids, 2012, 2012, p. 736837.

20.ESPINOZA, S.E., GUO, H., FEDARKO, N., DEZERN, A., FRIED, L.P., XUE, Q.L., LENG, S., BEAMER, B., AND WALSTON, J.D. J GERONTOI A Biol Sci Med Sci, 63, no. 5, 2008, p. 505-9.

21.ZULUAGA, M., GUEGUEN, V., PAVON-DJAVID, G., AND LETOURNEUR, D. Bioimpacts, 7, no.1, 2017, p. 1-3.

22.KOUSHAN, K., RUSOVICI, R., LI, W., FERGUSON, L.R., AND CHALAM, K.V. Nutrients, 5, no.5, 2013, p. 1823-39.

23.LI, S.Y. 11, no. 5, 2010, p. 2109-17.

24.FUNG, F.K.C., LAW, B.Y.K., AND LO, A.C.Y. PLoS One, 11, no.12, 2016.

25.KIM, J.E., CLARK, R.M., PARK, Y., LEE, J., AND FERNANDEZ, M.L. Nutr Res Pract, 6, no.2, 2012, p. 113-9.

26.NAVARRO, S.M., DARENSBOURG, C., CROSS, L., STOUT, R., COULON, D., ASTETE, C.E., MORGAN, T., AND SABLIOV, C.M. Ther Deliv, 5, no.11, 2014, p. 1191-201.

27.SIMON, L.C. AND SABLIOV, C.M. Drug Metab Rev, 46, no.2, 2014, p. $128-41$

28.SIMON, L.C. AND SABLIOV, C.M. Industrial Biotechnology, 9, no.1, 2013, p. 19-23.

29.MATEOS, R., LECUMBERRI, E., RAMOS, S., GOYA, L., AND BRAVO, L. J Chromatogr B Analyt Technol Biomed Life Sci, 827, no.1, 2005, p. 76-82.

30.VIRLAN, M.J., MIRICESCU, D., RADULESCU, R., SABLIOV, C.M., TOTAN, A., CALENIC, B., GREABU, M. MOLECULES, 21, no.2, 2016. 31.VIRLAN MJR, C.B., CIMPAN MR, COSTEA DE, GREABU M. Stoma Edu J, 4, no.1, 2017, p. 16-26.

32.BEUTLER, E., DURON, O., AND KELLY, B.M. J Lab Clin Med, 61, 1963, p. 882-8.

33.ESTERBAUER, H. AND CHEESEMAN, K.H. METHODS ENZYMOL, 186, 1990, p. 407-21.

34.MURANO, K., OGINO, H., OKUNO, T., ARAKAWA, T., AND UENO, $H$. BIOL PHARM BULL, 41, no.1, 2018, p. 92-98.

35.ABEBE, T., MAHADEVAN, J., BOGACHUS, L., HAHN, S., BLACK, M., OSEID, E., URANO, F., CIRULLI, V., AND ROBERTSON, R.P. JCI Insight, 2 , no.24, 2017.

36.SHARMA, S., PARMAR, A., KORI, S., AND SANDHIR, R. TrAC Trends in Analytical Chemistry, 80, 2016, p. 30-40.

37.CONSTANTINESCU, M.Z., VIRGOLICI, B., STEFAN, D.C.A., MIRICESCU, D., LIXANDRU, D., POPESCU, L., VIRGOLICI, H., GUBCEAC, E., MOHORA, M. Rev. Chim.(Bucharest),67, no.11, 2016, p. 2342. 38.CONSTANTINESCU, M.Z., VIRGOLICI, B., STEFAN, D.C.A., MIRICESCU, D., LIXANDRU, D., POPESCU, L., VIRGOLICI, H., GUBCEAC, E., and MOHORA, M. Rev. Chim.(Buchares)t,67, no.12, 2016, p. 2435 39.MARIN, E., BRICENO, M.I., and CABALLERO-GEORGE, C. Int J Nanomedicine, No. 8, 2013, p. 3071-90

Manuscript received:25.01.2018. 